\title{
The Girdled Snail Hygromia cinctella (Draparnaud, 1801) new to the Czech Republic
}

\author{
DAgMar Ř́íHOVÁ \& LuCIE JuŘIČKOVÁ
}

Dept. of Invertebrate Zoology, Faculty of Science, Charles University in Prague, Viničná 7, CZ-12844, Prague 2, Czech Republic; e-mail: Branta.bernicla@seznam.cz; lucie.jurickova@seznam.cz

Řínová D. \& JuřičKovÁ L., 2011: The Girdled Snail Hygromia cinctella (Draparnaud, 1801) new to the Czech Republic. - Malacologica Bohemoslovaca, 10: 35-37. Online serial at <http://mollusca.sav.sk> 16-Jun-2011.

\begin{abstract}
The Girdled Snail (Hygromia cinctella (Gastropoda: Pulmonata: Hygromiidae)) is recorded for the first time in the Czech Republic in Prague-Holešovice. Its occurrence in the Czech Republic has been expected since this terrestrial snail has been dispersing through neighbouring countries (Austria, Germany, Hungary, the Netherlands) in recent decades. The number of non-native molluscan species in the Czech Republic now stands at 21.
\end{abstract}

Key Words: Hygromia cinctella, Hygromiidae, Pulmonata, Czech Republic, invasive species, first record

\section{Introduction}

The family Hygromiidae comprises 21 species in the Czech Republic (HoRsÁK et al. 2010). The most recent newcomer - the Girdled Snail Hygromia cinctella (Draparnaud, 1801) - was added to this species list in May 2010, and its occurrence was confirmed in September 2010 and April 2011. This land snail was found in the harbour area of Prague-Holešovice near the Vltava River and its presence here has increased the number of non-native terrestrial snails in the Czech Republic to 12 ( 21 for all molluscan species). Hygromia cinctella is a representative of the family Hygromiidae. Its shell is conical, translucent, varying from dark brown to light yellow to almost translucent; usually pale. A light spiral band at its periphery emphasizes the keel (Fig. 1). The surface of the under site of the shell appears somewhat malleated. Fully-grown shells do not have a well-marked umbilicus which is narrow and almost closed, and such shells may reach up to $12 \mathrm{~mm}$ in diameter (CAmeron \& Redfern 1976, Kerney et al. 1983). The Girdled Snail lives typically in gardens, orchards, city parks and other anthropogenic biotopes (MIENIS 2006, 2008a, GöLLNITZ 2008), but it has also been considered a woodland species (KeRNEY et al. 1983).

According to KERNEY et al. (1983), H. cinctella originated in the Mediterranean Sea area extending along the Rhône Valley and into Switzerland; it is now spreading rapidly in Central Europe. It is known from England, Ireland, Wales (P.F. Whitehead, in litt.), the Netherlands, Germany, Austria, and Switzerland.

H. cinctella was first found in England in 1950 where it is regarded as naturalised (KERNEY et al. 1983) and invasive (Mienis 2008a) and had reached Ireland by 1999 (BECKmann \& Kobialka 2008). During the last three decades, H. cinctella has spread to Austria (since 1978; KERNEY et al. 1983, BECKMANN \& KoBIALKa 2008), Germany (since 1995; Kierdorf-Traut 2006, Wimmer 2006, BeckManN \& KobialKa 2008, and Göllnitz 2008), Hungary (since 1983; Kerney et al. 1983 and BECKMANn \& KobialKa 2008), the Netherlands (since 1995; Beckmann \& Kobialka 2008, Mienis 2006, 2007, 2008b), and Switzerland (since about 1980; BECKMANN \& KoBIALKa 2008). It also occurs in parts of France and Croatia (BECKMANN \& KobialKa 2008, Š TAMOL 2010).
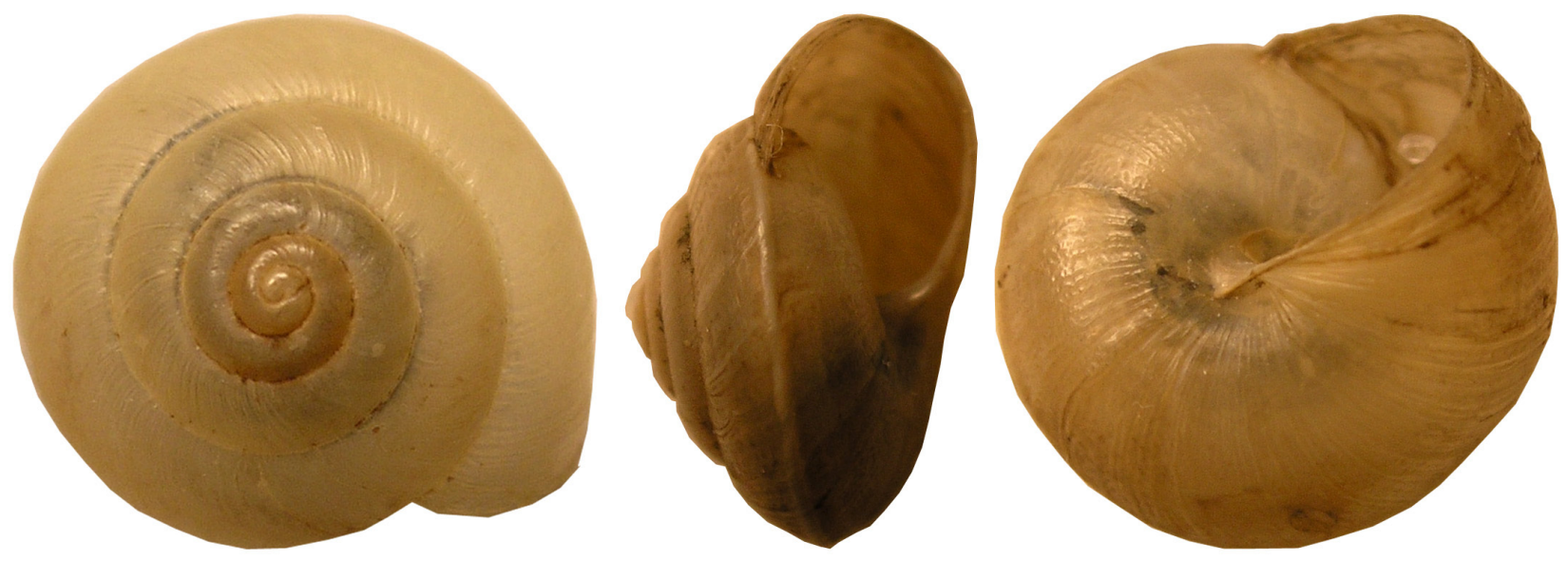

Fig. 1. The Girdled Snail (Hygromia cinctella (Draparnaud, 1801)) from its first known Czech locality in Prague-Holešovice. 
Some sources (Beckmann \& Kobialka 2008, Göllnitz 2008) mentioned an occurrence of this species in the Czech Republic, but this information could not be confirmed. The discovery of the population in Prague in 2010 thus is the first confirmed record of the species in the Czech Republic.

\section{Occurrence of Hygromia cinctella in the Czech Republic}

Hygromia cinctella was first found in Prague on May 19 2010 in the harbour area of Holešovice. Because H. cinctella lives here on a disturbed site and thus is prone to accidental extinction, its occurrence was monitored also at the beginning of September 2010 and in the middle of April 2011 with positive results. The determination was based on shell characters and specimens are deposited in the Department of Zoology, Charles University in Prague.

The site is situated near V Př́stavu Street $\left(50^{\circ} 6^{\prime} 33.117^{\prime \prime N}\right.$; $\left.14^{\circ} 27^{\prime} 13.011^{\prime \prime E}\right)$. It is an urban tip with old bricks, concrete, cement waste, timber and naturalised plants (Figs 2 and 3). In spring $2010 \mathrm{H}$. cinctella were found freely crawling on foliage of the polygonaceous plant Fallopia $\times$ bohemi$c a$ (an association with this genus was already mentioned in KAPPES et al. 2007), whilst in the autumn they were hidden under old planks and in a pile of grass clippings. In the spring 2011, some individuals were found hiding under planks and bricks, only a few of them were freely crawling on lower side of leaves of Taraxacum sp. Number of empty shells (many with remnants of a snail body) was found under bricks and dry vegetation. They probably originate from specimens which died during wintering, because such shell accumulation was not found in any of former visit of this place.
Interestingly, no adult specimens have been found during first two visits. The diameter of specimens sampled in May 2010 was $5.9 \mathrm{~mm}$ on average, whilst shells sampled in September were only $3 \mathrm{~mm}$ in diameter. Specimens found in April 2011 were bigger: they had $9 \mathrm{~mm}$ in diameter. Moreover, we found two empty shells bigger than $11 \mathrm{~mm}$.

A human introduction of $H$. cinctella to the Czech Republic is likely. Despite its claimed spread along rivers in Germany (Wimmer 2006, Beckmann \& KobialKa 2008), such passive introduction is improbable in the Czech Republic. The Girdled Snail could reach the Czech Republic by ship, car or by train from the nearby railway station, with plants or soil (Wimmer 2006, BeCKMANN \& KoBialkA 2008, Göllnitz 2008). The most probable way of introduction is the passive transport with building material. The highest snail density is in the urban tip beside a place with heaped building parts. The transport with plants and the origin of $H$. cinctella from a plant nursery is unlikely, there are not any cultivated plant species in the locality. In places with $H$. cinctella only common ruderal species occur: Acer negundo (L.), Anthemis arvensis (L.), Artemisia vulgaris (L.), Ballota nigra (L.), Daucus carota (L.), Erigeron annuus (L.), Fallopia $\times$ bohemica (Chrtek \& Chrtková), Hypericum perforatum (L.), Populus $\times$ euroamericana (Dode), Robinia pseudacacia (L.), Taraxacum sp., and Vicia cracca agg. (L.).

As mentioned above, Hygromia cinctella is not the first molluscan invader found in Prague-Holešovice. The only known Czech population of Cornu aspersum can be found here (JUŘIČKOVÁ \& KAPOUNEK 2009) as well as other invasive species such as Monacha cartusiana (O.F. Müller, 1774), Arion lusitanicus Mabile, 1868, and Cepaea nemoralis (L., 1758).

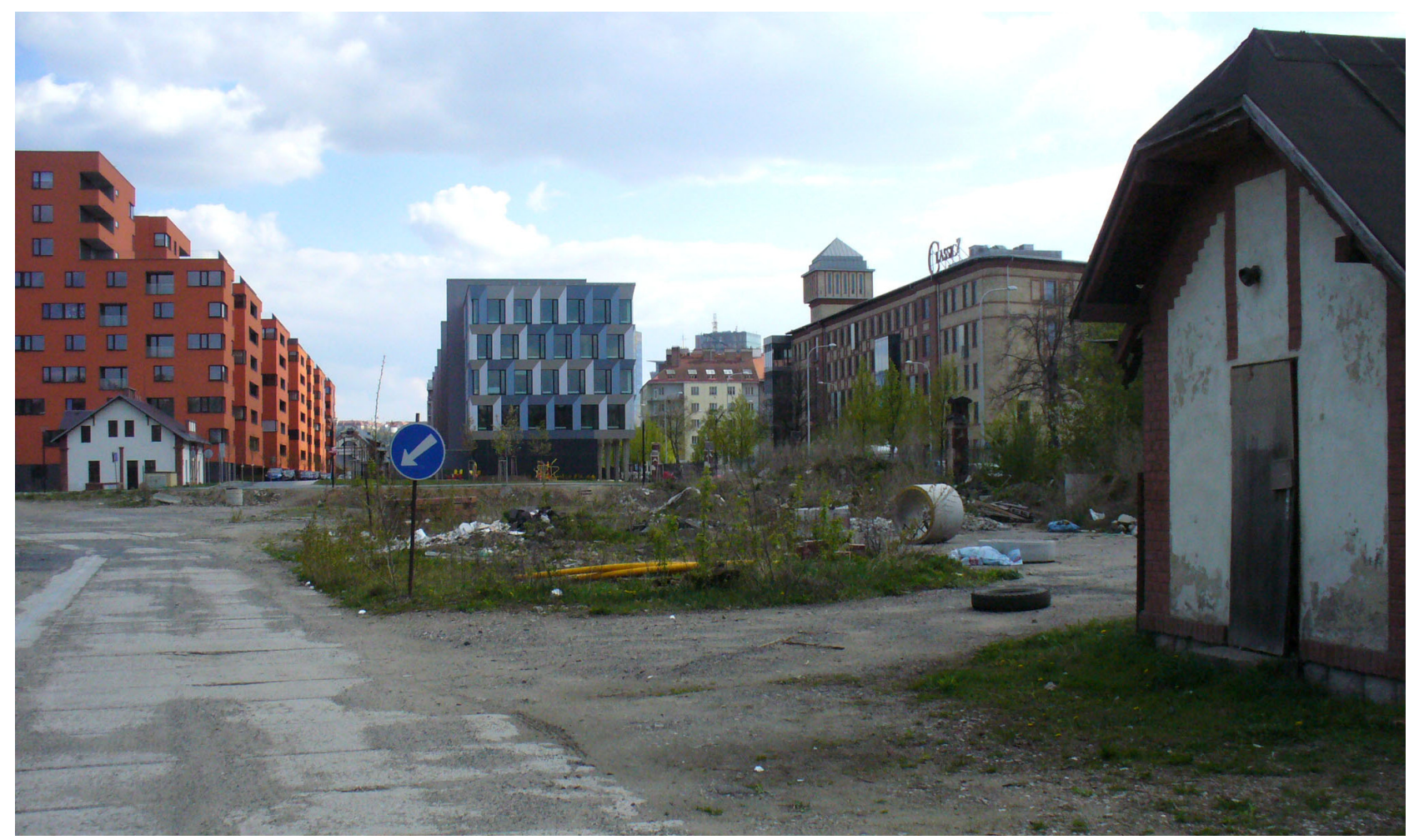

Fig. 2. The habitat of the Girdled Snail (Hygromia cinctella) in Prague-Holešovice, V Př́stavu Street. 


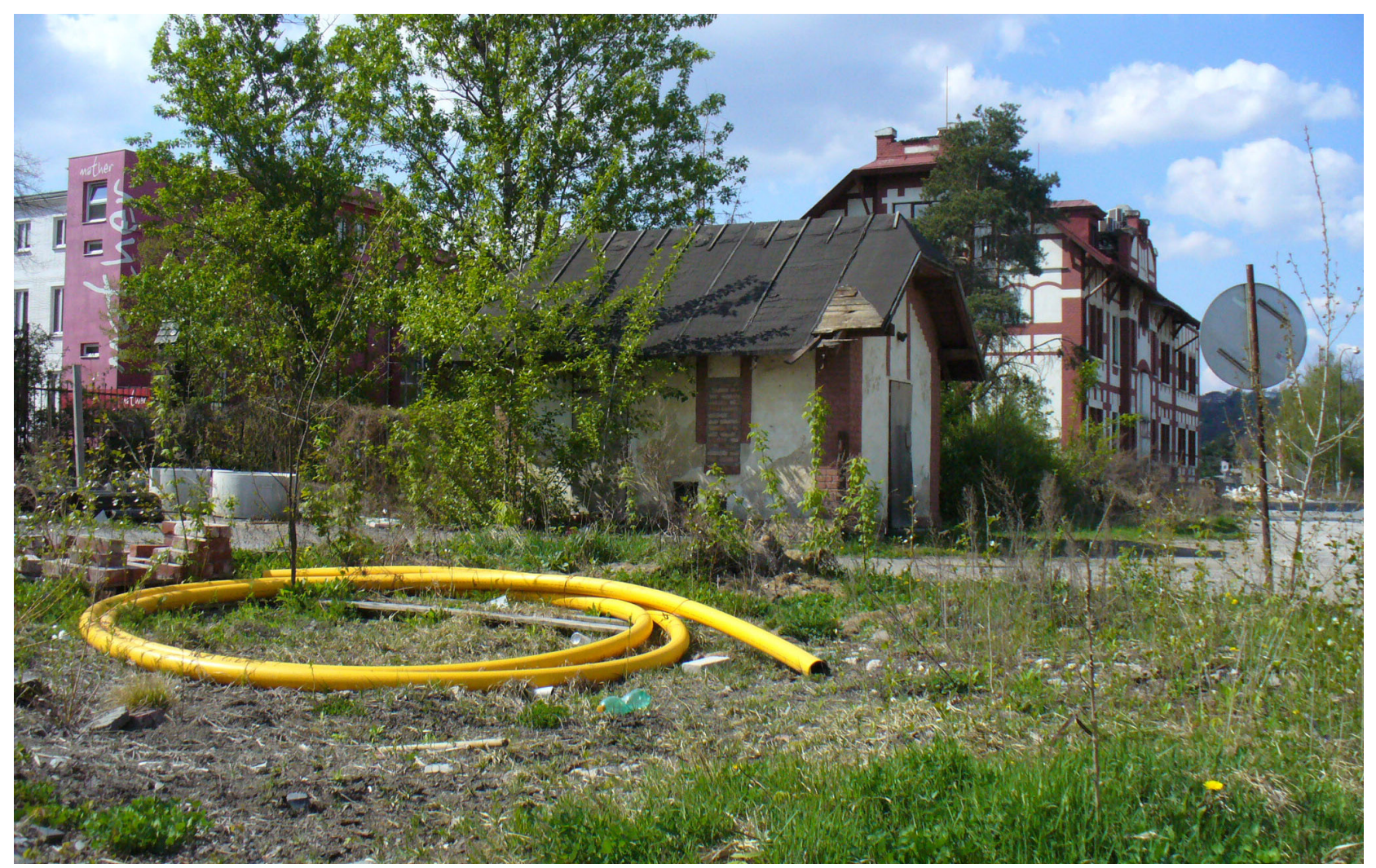

Fig. 3. Detailed view on the site that harbours a population of Hygromia cinctella in Prague-Holešovice.

\section{The future of the Girdled Snail in Prague}

Hygromia cinctella was able to overwinter the cold winter 2010/2011 in Prague-Holešovice and therefore we can consider this species as the newest established member of Czech molluscan fauna. We suppose that $H$. cinctella will spread in the Czech Republic.

\section{Acknowledgement}

The Prague locality of Hygromia cinctella was discovered during a field excursion of the Biological Club for High-School Students under the supervision of the first author of this paper. We thank Barbora Frýdová, Jiří Hadrava, and Matěj Semerák for their patience because the objective of their field excursion was monitoring of another non-native molluscan species, Cornu aspersum, not the discovery of a land snail species new for the Czech Republic. Miss Veronika Szalontayová kindly helped with English language editing. Three reviewers - K. Jordaens, H. Kobialka, and P.F. Whitehead - considerably improved this paper. This study was supported by MSMT project 0021620828 .

\section{References}

CAmeron R.A.D. \& Redfern M., 1976: British Land Snails. - Synopses of the British Fauna (New Series) No. 6. Academic Press London, $64 \mathrm{pp}$.

Beckmann K.-H. \& KobialKa H., 2008: Hygromia cinctella (Draparnaud, 1801) auf dem Eroberungszug durch Deutschland (Gastropoda: Hygromiidae). - Club Conchylia Informationen, $39(1 / 2): 34-41$.

GöLlNITZ U., 2008: Nachweis von Hygromia cinctella (Mollusca: Gastropoda) in Rostock. - Archiv der Freunde der Naturgeschichte Mecklenburgs, 47: 77-79.
Horsák M., JuřičKová L., Beran L., ČejKa T. \& DvořÁK L., 2010: Annotated list of mollusc species recorded outdoors in the Czech and Slovak Republics. - Malacologica Bohemoslovaca, Suppl. 1: 1-37. Online serial at $<\mathrm{http}: / /$ mollusca.sav.sk $>$ 10-Nov-2010.

JuŘIČKOVÁ L. \& KAPOUNEK F., 2009: Helix (Cornu) aspersa (O.F. Müller, 1774) (Gastropoda: Helicidae) in the Czech Republic. - Malacologica Bohemoslovaca, 8: 53-55. Online serial at $<$ http://mollusca.sav.sk> 18-Nov-2009.

KaPpes H., LAY R. \& TopP W., 2007: Changes in different trophic levels of litter-dwelling macrofauna associated with giant knotweed invasion. - Ecosystems, 10: 734-744.

Kerney M.P., Cameron R.A.D. \& Jungbluth J.H., 1983: Die Landschnecken Nord- und Mitteleuropas. Ein Bestimmungsbuch für Biologen und Naturfreunde. - Verlag Paul Parey. Hamburg und Berlin, 384 pp.

KieRDORf-Traut G., 2006: Erster Nachtrag zur Fauna der LandGehäuseschnecken Südtirols (Mollusca: Gastropoda). - Gredleriana, 6: 277-286.

MienIs H.K., 2006: New Data Concerning the Presence of Hygromia cinctella in Purmerend (in Dutch). - DeKreukel, 42 (9): 142.

MienIS H.K., 2007: News about gastropods from Monnickendam, the Netherlands (in Dutch). - DeKreukel, 43 (1): 5-7.

MienIs H.K., 2008a: Various observations concerning the Girdled Snail, an invasive species. - The Reading Naturalist, 60: 32.

MienIs H.K., 2008b: Invasion of the Girdled Snail Hygromia cinctella in Purmerend and elsewhere in the Netherlands (in Dutch). - Spirula, 364: 101-103.

ŠTAmOL V., 2010: A list of the land snails (Mollusca: Gastropoda) of Croatia, with recommendations for their Croatian names. - Natura Croatica, 19 (1): 1-76.

WiMmer W., 2006: Hygromia cinctella (Draparnaud, 1801) auf Gut Sunder, Landkreis Celle, Niedersachsen (Gastropoda: Hygromiidae). - Braunschweiger Naturkundliche Schriften, 7 (3): 671-675. 